\title{
PREDSTAVENIE PROJEKTU PARTNERSKÝCH KNIŽNÍC CVTI SR
}

Mgr. Dávid Baranko; david.baranko@cvtisr.sk; (Centrum vedecko-technických informácií SR)

\begin{abstract}
Spoločnost' sa rapídnou rýchlost'ou transformuje v dôsledku 4. priemyselnej revolúcie, vplyvom klimatických zmien, posunom života l'udí do online prostredia či najnovšie pandémiou. Knižnice, ako otvorené a dostupné miesta pre širokú verejnost', by mali využit' svoju pozíciu a pripravit' verejnost' v rámci možnostína blízku budúcnost'. Centrum vedecko-technických informácii SR sa práve preto rozhodlo aktívne podporit' verejné knižnice a vytvorit' siet’ spolupracujúcich knižníc, ktoré budú spoločne podporovat' nové digitálne zručnosti obyvatel'ov a prinášat' inovatívne služby v rámci projektu Partnerské knižnice. Článok predstavuje možnosti zapojenia sa do projektu, jeho význam pre knižnice i širokú verejnost', doterajšie aktivity a pripravované plány do budúcnosti.
\end{abstract}

https://doi.org/10.52036/1335793X.2021.3-4.48-52

Knižnice už dávno neslúžia len ako miesta na uchovávanie a vypožičiavanie fyzických dokumentov. S nástupom internetu a digitálnych technológií sa prirodzene transformujú na centrá vzdelávacieho, kultúrneho či komunitného charakteru. Túto skutočnost' si uvedomuje aj súčasná Vláda SR, ktorá vo svojom programovom vyhlásení uvádza, že „podporí rozvoj knižníc ako miest poskytujúcich vzdelávanie a informačné zázemie, najmä v oblasti IKT zručností, služieb e-Government, verejného zdravia, ekológie a sprístupňovania digitálnych informačných zdrojov širokej verejnosti“ ${ }^{1}$ s. 124 .

Centrum vedecko-technických informácií SR (CVTI SR), ako vedecká knižnica a národné informačné centrum pre vedu, techniku, inovácie a vzdelávanie, sa plne stotožňuje s uvedeným vyhlásením a citlivo vníma celospoločenské zmeny nielen $v$ dôsledku nastávajúcej 4. priemyselnej revolúcie. Považujeme za nevyhnutné prispiet ' $k$ podpore nových digitálnych gramotností občanov SR a podporit' slovenské knižnice tak, aby mali svoje nezastupitel'né miesto aj $v$ blízkej budúcnosti. $\checkmark$ tomto kontexte si uvedomujeme potenciál najmä krajských a regionálnych verejných knižníc, ktoré sú blízko $\mathrm{k}$ občanom všetkých vekových kategórií a vo väčšine prípadov disponujú vhodnými priestormi na realizáciu inovatívnych služieb, podujatí a vzdelávacích aktivít pre širokú verejnost'.

Na základe uvedených skutočností a dlhoročných skúseností s projektom IT Akadémia - vzdelávanie pre 21. storočie, kreatívnou dielňou Fablab, moderným digitalizačným pracoviskom, rozširujúcou ponukou elektronických informačných zdrojov či chutou zavádzat nové a inovatívne knižnično-informačné služby sme sa rozhodli vyvinút vlastnú iniciatívu, ktorú pracovne nazývame ako projekt: „Partnerské knižnice“.

\section{O PROJEKTE}

Ciel’om projektu Partnerské knižnice je intenzifikácia využitia knižníc ako miest pre získanie všetkých druhov informácií, celoživotného vzdelávania, počítačových a Industry 4.0 zručností, rozvoja kreativity, podpory inovácií a podnikania pre všetky vekové skupiny obyvatelov.

Projekt vznikol na základe myšlienky vytvorenia siete aktívne spolupracujúcich knižníc, ktoré budú spoločne zavádzat' nové inovatívne služby a slúžit' verejnosti vo vyššie spomenutých oblastiach.

Do projektu sa môže zapojit' akákol'vek knižnica alebo inštitúcia, ktorá má chut' spolupracovat na vopred dohodnutých aktivitách, ktorých realizácia bude vo verejnom záujme. Podmienkou zapojenia sa je uzavretie dohody o spolupráci s CVTI SR. Dohoda sa uzatvára na dobu určitú, knižnici ňou nevznikajú žiadne finančné záväzky a partnerská knižnica si môže vopred vybrat' želané oblasti spolupráce.

Do konca októbra 2021 sa do projektu zapojilo 34 knižníc, z toho väčšina sú regionálne alebo krajské verejné knižnice.

\section{VEREJNÁ KNIŽNICA AKO PARTNER CVTI SR}

Partnerská knižnica v prípade záujmu získa možnost' zabezpečenia digitalizácie, komplexného spracovania, online sprístupnenia a archivácie dokumentov z vlastného fondu. Digitalizácia prebieha priamo v CVTI SR alebo $v$ priestoroch partnerskej knižnice. Pre tento účel zaobstaralo digitalizačné pracovisko CVTI SR tzv. 


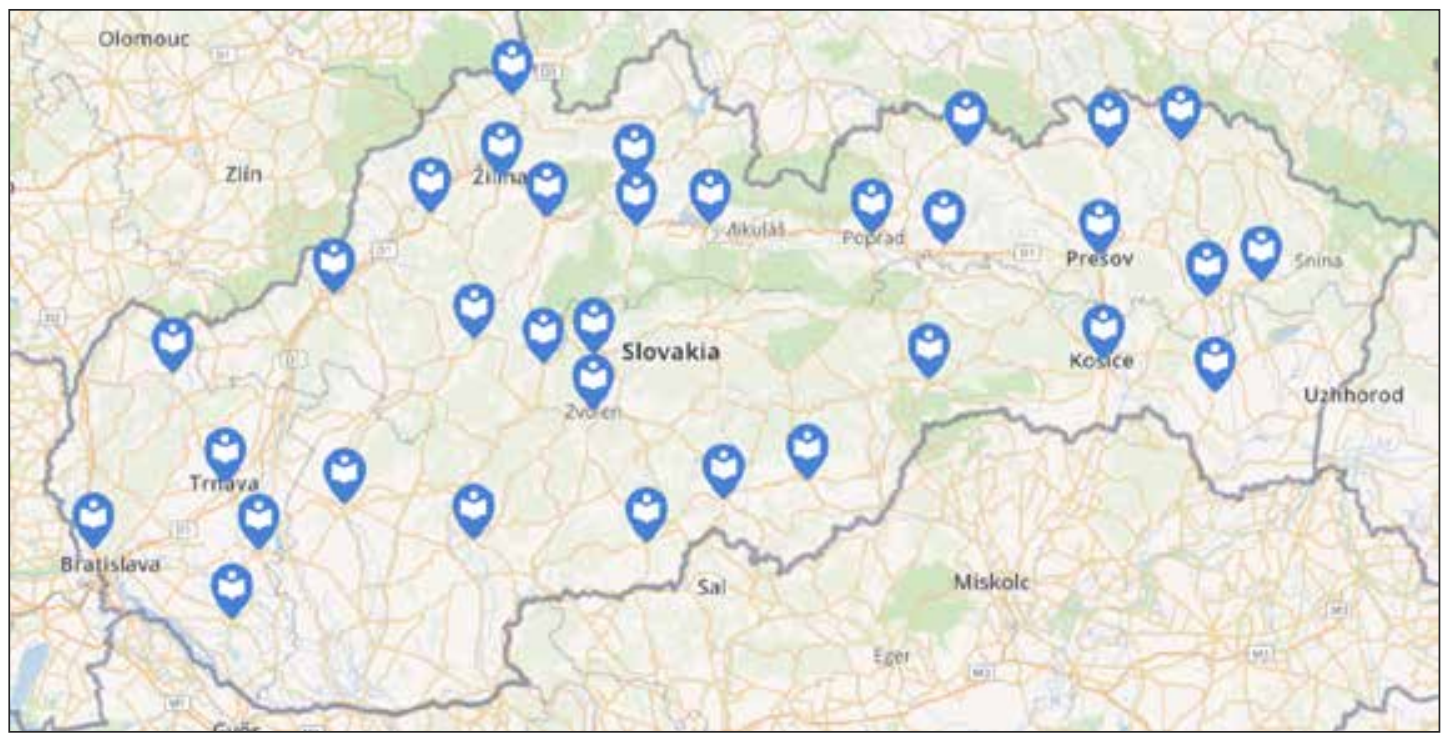

Obr. č. 1 Mapa partnerských knižníc CVTI SR

„putovný knižný skener", ktorý bude zapožičaný tým knižniciam, ktoré vedia vyčlenit́ vlastný personál na skenovanie a spracovanie. Okrem zapožičania skenera je samozrejmostou aj komplexné zaškolenie odbornými pracovníkmi digitalizačného pracoviska a následná technická podpora $v$ prípade otázok či problémov. Následný postprocessing si po potrebnom zaškolení a sprístupnení profesionálneho softvéru môže robit’ partnerská knižnica tiež sama. Digitalizáty budú po sprevádzkovaní digitálnej knižnice sprístupnené $v$ priestoroch partnerskej knižnice.

CVTI SR tiež prispieva $k$ celoživotnému vzdelávaniu zamestnancov partnerskej knižnice prostredníctvom kurzov, seminárov či workshopov. Zabezpečíme realizáciu nových služieb v partnerskej knižnici, ktorá navyše získa možnost' podiel'at' sa na tvorbe metodických a koncepčných materiálov $v$ oblasti identifikácie a realizácie nových modelov poskytovania knižnično-informačných služieb v rámci siete partnerských knižníc. CVTI SR plne podporí a zastreší vybudovanie a sprevádzkovanie kreatívnej dielne Fablab či Virtuálnej študovne odbornej literatúry. $V$ neposlednom rade bude partnerská knižnica zapojená do projektov realizovaných ministerstvom školstva a CVTI SR.

\section{VEREJNOSŤ AKO CIEL'OVÁ SKUPINA PROJEKTU}

Našim dlhodobým zámerom je podporit prípravu verejnosti na blízku budúcnost', v ktorej bude trh práce značne ovplyvnený 4. priemyselnou revolúciou a dôsledkami klimatických zmien. CVTI SR preto poskytne partnerským knižniciam plnú súčinnost' pri podpore digitálnej gramotnosti nielen svojich používatel'ov.
Občan tak v príjemnom a známom prostredí svojej miestnej knižnice nájde aj miesto, v ktorom sa môžu deti hravou formou učit programovat', seniori získat základy práce s IKT technológiami, zamestnaní i nezamestnaní rozvíjat nové digitálne zručnosti, ktoré im pomôžu uplatnit' sa na dynamickom trhu práce. Knižnica by sa tak z časti mohla stat aj centrom podpory IKT kompetencií, kde budú vítané všetky vekové kategórie občanov. Navyše vd'aka výrobným technológiám, ako napríklad 3D tlačiareň, môže knižnica slúžit aj ako kreatívna dielňa, ktorú využijú študenti nielen technických odborov, ale aj začínajúci podnikatelia.

Zároveň považujeme za nevyhnutné zjednodušit' a zefektívnit́ prístup $\mathrm{k}$ elektronickým informačným zdrojom (d'alej len EIZ). Aj kvôli tomu sme zrušili poplatky za registrácie a chystáme nový systém online registrácií. Portfólio EIZ neustále rozširujeme, najnovšie o službu Bookport, ktorá umožňuje prístup k viac ako 8500 e-knihám z rôznych oblastí (odborná literatúra i beletria) v českom jazyku nielen z vydavatel'stva Grada. Práve verejné knižnice môžu prispiet' $k$ rozširovaniu povedomia o možnostiach bezplatného prístupu k odborným e-zdrojom. Verejnost' tak získa vo svojej miestnej knižnici informačných špecialistov, ktorí budú schopní pomôct' s vyhl'adávaním odborných informácií a spracovávat' komplexné rešerše z EIZ CVTI SR.

Používatel' by tiež v rámci možností mal získat' prístup ku knižnično-informačným službám CVTI SR prostredníctvom svojej miestnej knižnice. $V$ konečnom dôsledku možno konštatovat', že všetky aktivity uvedené v predošlej kapitole budú prospešné aj pre širokú verejnost'. 


\section{DOTERAJŠIE AKTIVITY}

\section{1 Školenia a workshopy}

Spoluprácu s partnerskými knižnicami sme aktívne začali v priebehu apríla/mája 2021, kedy sme pre knižnice realizovali sériu online školení, ktorých sa celkovo zúčastnilo 150 knihovníkov z 26 partnerských knižníc. Ciel'om školení bolo predstavenie elektronických informačných zdrojov CVTI SR relevantných pre verejné knižnice spojené so základmi vyhl'adávania a rešeršovania.

Na zrealizované školenie nadviazalo druhé kolo online školení, ktorých sa zúčastnilo 84 knihovníkov z 25 partnerských knižníc, na ktorom získali knihovníci nové poznatky $v$ expertnom vyhladávaní a spracovávaní rešerší vo vybraných e-zdrojoch CVTI SR.

Partnerské knižnice CVTI SR sme pozvali na podujatie Bibliosféry 2021, kde bol projekt oficiálne predstavený a partnerským knižniciam boli odprezentované inovatívne služby, napríklad možnost' využitia umelej inteligencie v službách knižníc alebo rozvoja kreativity prostredníctvom 3D tlače či micro:bitov. $V$ rámci časti Expo boli knižniciam odprezentované praktické ukážky digitalizácie prostredníctvom putovného knižného skenera $s$ následným postprocessingom. Predstavili sme tiež technológie využívané v kreatívnych dielňach Fablab. Účastníkom sme predviedli tlačenie objektov prostredníctvom 3D tlačiarne a bola im tiež predstavená práca $\mathrm{s}$ micro:bitmi (programovatel'ný mikropočítač), vd'aka ktorým môžu verejné knižnice vzbudit' u detí záujem o programovanie, robotiku či 3D modelovanie. Partnerské knižnice tiež mali možnost' osobných konzultácií k používaniu elektronických informačných zdrojov CVTI SR a spracovávaniu rešerší.

Priaznivú letnú pandemickú situáciu sme následne využili na workshopy, respektíve školenia priamo v partnerských knižniciach. Kolegovia z kreatívnej dielne Fablab Ing. Eva Kalužákova a Ing. Jozef Vaško v priebehu augusta a septembra navštívili Podtatranskú knižnicu v Poprade ${ }^{2}$, Krajskú knižnicu Karola Kmet'ka v Nitre, Verejnú knižnicu Mikuláša Kováča v Banskej Bystrici a Verejnú knižnicu Michala Rešetku v Trenčíne. Uvedené knižnice hostili 2-dňové školenie zamerané na rozvoj kreativity, na ktorom sa zúčastnili aj knihovníci z okolitých partnerských knižníc. Ciel'om školenia bolo získat základne zručnosti v práci s microbitom a 3D tlačou tak, aby knihovníci vedeli prostredníctvom týchto technológií rozvíjat' kreativitu a podporovat' digitálnu gramotnost' svojich používatel'ov. Vrátane školenia priamo vo Fablab Bratislava sme tak celkovo vyškolili 49 knihovníkov z 19 partnerských knižníc, ktorí majú potrebné kompetencie na vedenie základných workshopov s micro:bitmi a 3D tlačou. Vybraným partnerským knižniciam, ktoré prejavili záujem, kolegovia pomohli zrealizovat' aj workshopy priamo s det'mi a niektoré knižnice už podujatia na rozvoj kreativity a podporu digitálnej gramotnosti zrealizovali aj samostatne $^{3}$. Viac o školeniach, workshopoch a skúsenostiach našich kolegov sa dozviete v nasledujúcom člán-

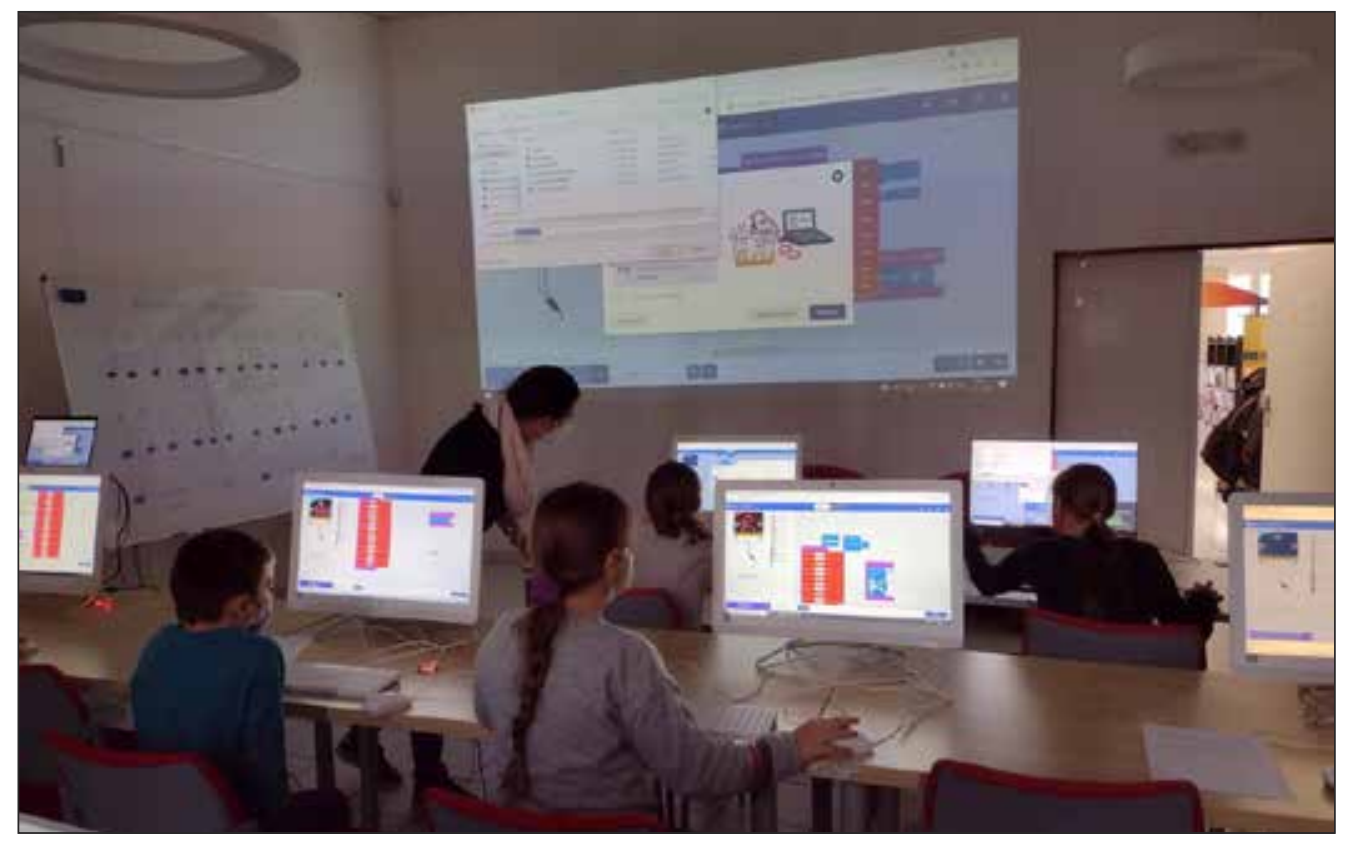

Obr. č. 2 Workshop s micro:bitmi pre deti realizovaný knihovníkmi v Krajskej knižnici v Žiline 
ku Vytváranie tvorivosti a počítačovej zručnosti pre budúcnost' v knižniciach Slovenska.

Prezenčné školenia $v$ partnerských knižniciach sme realizovali aj na tému expertného vyhl'adávania a rešeršovania $v$ elektronických informačných zdrojoch CVTI SR. Oproti online školeniam malo formu cvičení a konzultácií a lektori navštívili Krajskú knižnicu v Žiline, Knižnicu Juraja Fándlyho v Trnave, Knižnicu P.O. Hviezdoslava v Prešove a Verejnú knižnicu Mikuláša Kováča v Banskej Bystrici. Uvedené knižnice boli opät' otvorené aj pre knihovníkov z okolitých partnerských knižníc a celkovo sa školení zúčastnilo 49 knihovníkov z 20 knižníc.

\subsection{Digitalizácia}

V septembri 2021 sme začali s digitalizáciou fondov partnerských knižníc. Na základe vol'ných personálnych kapacít knižnice na skenovanie a postprocessing, regionálnej alebo celonárodnej hodnoty zbierky a iných faktorov sa stanovilo poradie digitalizačného procesu.

Samoobslužný putovný knižný skener bol, ako prvej partnerskej knižnici, zapožičaný Žitnoostrovskej kniž-

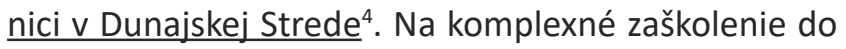
procesu skenovania postačil jeden deň a kolegovia z partnerskej knižnice za necelé dva mesiace naskenovali viac ako osem tisíc strán regionálnych periodík zo svojho fondu (napr. Družstevná dedina, Horný Žitný ostrov a iné). Po ukončení procesu skenovania by mal byt' knižnici zapožičaný počítač s potrebným vybavením na postprocessing a putovný skener tak môže byt' poskytnutý d'alším záujemcom, konkrétne Galantskej knižnici v Galante, Gemerskej knižnici Pavla Dobšinského $v$ Rožňave, Zemplínskej knižnici $v$ Trebišove, Hornozemplínskej knižnici vo Vranove nad Topl'ou či Verejnej knižnici Michala Rešetku v Trenčíne.

$\checkmark$ novembri sa začal aj proces digitalizácie dokumentov partnerských knižníc priamo $v$ digitalizačnom pracovisku CVTI SR. Prvou zdigitalizovanou zbierkou bude regionálne periodikum Kysucké noviny, ktorou disponuje Kysucká knižnica v Čadci. Hned' nato sa začne s digitalizáciou zbierok Záhorskej knižnice v Senici, Krajskej knižnice Karola Kmet́ka v Nitre, Krajskej knižnice Ĺudovíta Štúra vo Zvolene a Novohradskej knižnice $v$ Lučenci. Momentálne prebieha pasportizácia dokumentov s ciel'om zamedzenia duplicitného skenovania. O digitalizácií bude publikovaný samostatný článok.

\section{3 Ďalšie aktivity}

Pre partnerské knižnice, ktoré absolvovali úvodné školenie do práce s micro:bitom a 3D tlačou, sme zaviedli novú službu - výpožičky micro:bitov. Ak knižnica nemá možnost' si zariadenie zakúpit' alebo si chce organizáciu vlastných workshopov iba skúsit', poskytneme jej na niekol'ko mesiacov celé sady micro:bitov „Učíme s hardvérom", ktorých sme doteraz vypožičali 42 kusov. V rámci partnerstva ide aj o rôzne "drobné" služ-

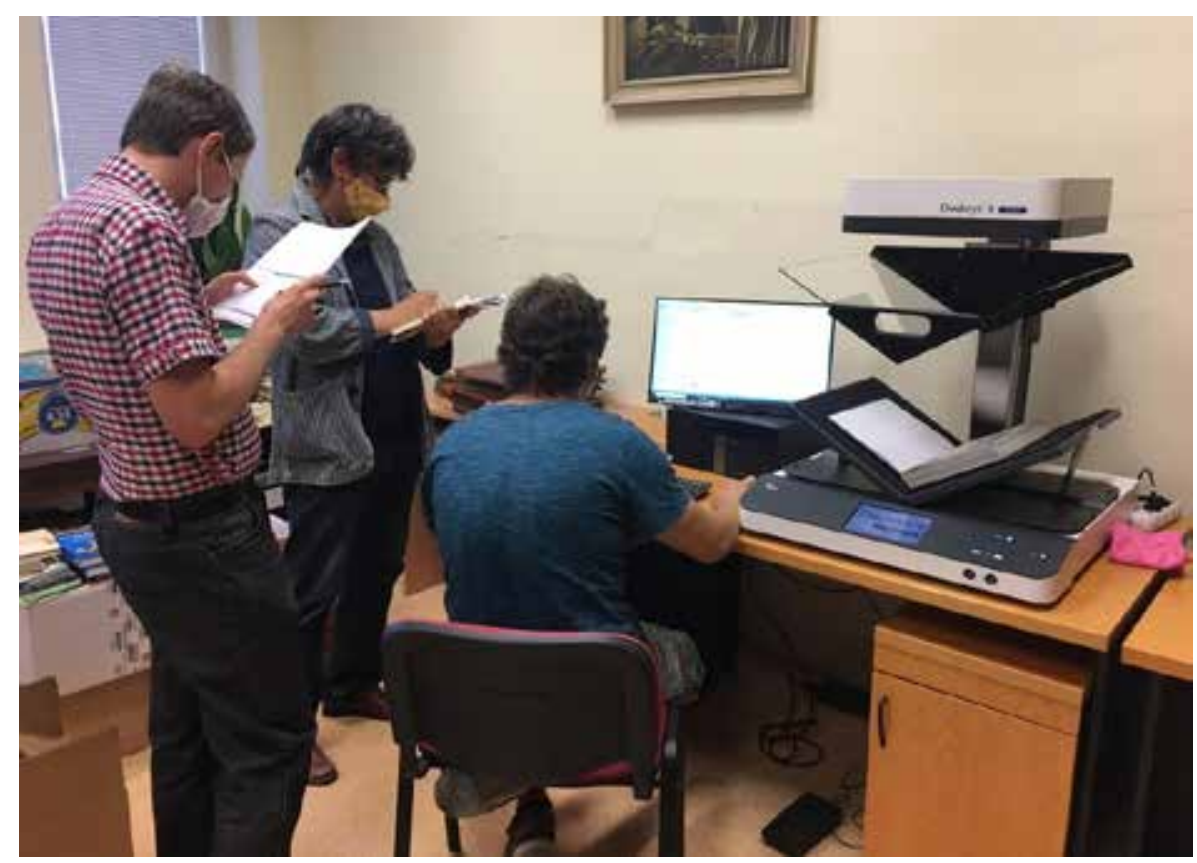

Obr. č. 3 Školenie pracovníkov Žitnoostrovskej knižnice do procesu skenovania 
by a pomoc. Či už je to poradenstvo pri kúpe vhodnej 3D tlačiarne, prerobenie loga knižnice do vektorového formátu vysokej kvality pre potreby propagačných materiálov, konzultácie pri podávaní žiadostí na grantové výzvy na nákup technológií pre podporu digitálnej gramotnosti či sprostredkovanie spolupráce $s$ inými organizáciami.

\section{Budúcnost' projektu a pripravované aktivity}

$\checkmark$ budúcnosti sa plánuje projekt transformovat' do konzorcia s názvom Knižnice pre Slovensko, ktoré bolo oficiálne predstavené už na podujatí Bibliosféry 2021. Konzorcium bude mat' svoju správnu radu, ktorej pripravované zloženie je nasledovné: 3 členovia z partnerských knižníc, 2 členovia z SK8, 2 členovia z CVTI SR, 1 člen Slovenskej lekárskej spoločnosti, 1 člen za príslušné ministerstvo a tajomník.

Kolegovia z kreatívnej dielne FabLab majú už teraz pripravené nové aktivity pre partnerské knižnice zamerané na vzdelávanie a rozvoj kreativity, najnovšie napríklad workshop s programovatel'ným robotom s názvom Ozobot. Pripravuje sa tiež nový koncept online školení zameraných na prácu s e-zdrojmi CVTI SR - kratšie, no o to viac podrobnejšie školenie venované konkrétnej databáze. Plánuje sa marketingová kampaň, nové služby či podujatia.

Stále sme iba na začiatku a čaká nás vel'a práce. Náš plán je ambiciózny a na realizovanie všetkých našich zámerov bude nevyhnutná podpora aj zo strany jednotlivých ministerstiev či súkromných firiem. Oslovovanie potencionálnych partnerov a rokovania prebiehajú. Budeme radi za každé partnerstvo a spoluprácu, ktoré bude prospešné pre verejnost'.

Záverom by sme radi podotkli, že projekt nechceme koncipovat' iba jednostranne smerom z CVTI SR na verejné knižnice. Chceme, aby zapojené knižnice boli aktívne, komunikovali medzi sebou, prinášali nové nápady či vízie do budúcnosti a najmä sa podporovali a inšpirovali, napríklad zdiel'aním skúseností zo zrealizovaných workshopov a podobne.

Ďalšie informácie o projekte možno nájst' na webovej stránke Partnerské knižnice ${ }^{5} v$ rámci nového webu vedeckej knižnice CVTI SR.

Použité zdroje:

1. Programové vyhlásenie vlády Slovenskej republiky na obdobie rokov 2021 - 2024 [online]. 2021 [cit. 2021-10-25]. Dostupné na: https://www.nrsr.sk/web/Dynamic/DocumentPreview.aspx?DoclD $=494677$

2. Už nielen knihovníci, ale aj digitálne zruční lektori. CVTI SR [online]. Bratislava: Centrum vedecko-technických informácií SR, 2021 [cit. 2021-10-25]. Dostupné na: https://www.cvtisr.sk/aktuality-pre-odbornu-verejnost/uz-nielen-knihovnici-ale-aj-digitalne-zrucni-lektori.html?page id $=40433$

3. V základnom programovaní a 3D tlači školia už aj knihovníci z projektu partnerských knižníc CVTI SR. CVTI SR [online]. Bratislava: Centrum vedecko-technických informácií SR, 2021 [cit. 2021-11-26]. Dostupné na: https://www.cvtisr.sk/aktuality-pre-odbornu-verejnost/v-zakladnom-programovani-a-3d-tlaci-skolia-uz-aj-knihovnici-z-projektu-partnerskych-kniznic-cvti-sr. html?page id=41524

4. Začína sa digitalizácia fondov verejných knižníc. Putovný knižný skener vyrazil do prvej partnerskej knižnice. CVTI SR [online]. Bratislava: Centrum vedecko-technických informácií SR, 2021 [cit. 2021-11-26]. Dostupné na: https://www.cvtisr.sk/aktuality-pre-odbornu-verejnost/zacina-sa-digitalizacia-fondov-verejnych-kniznic.-putovny-knizny-skener-vyrazil-do-prvej-partnerskej-kniznice.html?page id=40958

5. Partnerské knižnice. Národná vedecká knižnica - CVTI SR [online]. Bratislava: Centrum vedecko-technických informácií SR, 2021 [cit. 2021-11-26]. Dostupné na: https://nvk.cvtisr.sk/o-kniznici/ partnerske-kniznice/ 